\title{
Histological lung description of Caracara plancus (Miller, 1777) (Falconiformes, Falconidae) and Ardea alba (Linnaeus, 1758) (Pelecaniformes, Ardeidae)
}

\author{
Bianca da Silva Salmon Pompeu \\ Verônica Clemente Villar Martini \\ Luís Gustavo Oliveira Picorelli \\ Jeferson Rocha Pires \\ Bruno Murilo da Silva Freitas \\ Jonathas da Cruz Farias \\ Universidade Estácio de Sá, Centro de Ciências Biológicas e da Saúde \\ Estrada Boca do Mato, Vargem Pequena, CEP 22783-320, Rio de Janeiro, RJ - Brasil \\ * Autor para correspondência \\ salmonbia@hotmail.com
}

Submetido em 12/04/2014

Aceito para publicação em 24/08/2014

\section{Resumo}

Descrição histológica do pulmão de Caracara plancus (Miller, 1777) (Falconiformes, Falconidae) e Ardea alba (Linnaeus, 1758) (Pelecaniformes, Ardeidae). Os estudos histológicos em aves silvestres ainda são incipientes, levando em consideração a grande diversidade de espécies e a dificuldade de obter material para análise. Em virtude dessa escassez, objetivou-se descrever a morfologia microscópica do pulmão de duas aves silvestres terrestres. Para tanto, foi utilizado um exemplar de Ardea alba - Linnaeus, 1758 (garça-branca) - e um exemplar de Caracara plancus - Miller, 1777 (gavião caracará) -, que foram levados ao Centro de Reabilitação de Animais Silvestres (CRAS) da Universidade Estácio de Sá (UNESA), em Vargem Pequena-RJ, por membros da sociedade civil e órgãos de cuidado e proteção do governo; entretanto, não resistiram às lesões e vieram a óbito de maneira natural. Os animais foram dissecados e seus pulmões foram fixados em solução aquosa de formaldeído a $10 \%$, para aplicação da técnica histológica de rotina, revelando estrutura diferenciada do órgão com um padrão de ramificação bronquial composto por mesobrônquio, brônquio secundário e parabrônquio, bem como pela ausência de alvéolos pulmonares clássicos, cuja função é desempenhada pelos capilares aéreos. Os resultados apontam a semelhança microscópica com aves domésticas e confirmam a complexa arquitetura para amplificar a troca gasosa.

Palavras-chave: Aves silvestres; Garça-branca; Gavião caracará; Histologia; Pulmão

\section{Abstract}

Histological studies in wild birds are still incipient, taking into account the great diversity of species and the difficulty to obtain material for analysis. Due to this scarcity, we aimed to describe the microscopic lung morphology of two terrestrial wild birds. To do this, we used a specimen of Ardea alba - Linnaeus, 1758 (great 
egret) - and a specimen of Caracara plancus - Miller, 1777 (southern caracara)-, which were taken to the Center for Rehabilitation of Wild Animals (CRAS) of Universidade Estácio de Sá (UNESA), in Vargem Pequena, Rio de Janeiro, Brazil, by members of civil society and government care and protection agencies; however, they did not survive their injuries and died naturally. The animals were dissected and their lungs were fixed in 10\% formaldehyde aqueous solution, to apply routine histological technique, revealing a differentiated structure in the organ with a bronchial branching pattern that consists of mesobronchus, secondary bronchus, and parabronchus, as well as absence of classical lung alveoli, whose function is performed by air capillaries. Results point out the microscopic resemblance to poultry and confirm the complex architecture to enhance gas exchange.

Key words: Lung; Great egret; Histology; Southern caracara; Wild birds

\section{Introduction}

Great egret and southern caracara are bird species found in the Brazilian avifauna and, although having distinct habits and anatomical features, they are classified as terrestrial wild birds. They live along with other birds and animals, both in the countryside and in the cities (SICK, 1997).

Caracara is a rural omnivorous bird of prey belonging to the order Falconiformes, Falconidae family, which, despite being considered as a typically Brazilian bird, has a wide geographic distribution, inhabiting any open area. Its food is very varied; it eats both dead and living animals, regardless of their quality. They also feed on amphibians, annelids, fruits, and seeds (DUKES, 1996; SICK, 1997).

Great egret, known in Brazil as "garça-branca", is a migratory bird belonging to the order Pelecaniformes, Ardeidae family, living in groups of several animals on the edge of lakes, rivers, and swamps. The species has a global geographical distribution, feeding preferably on fish and aquatic insects (larvae); however, individuals eat amphibians, reptiles, and small mammals (SICK, 1997).

The respiratory system of birds is the most efficient among vertebrates, consisting of airways, lungs, and air sacs. It has many features of its own, among which stand out modifications involving gas exchange that take place in the lung, which is a small and compact organ, adhered to the chest wall, having a fixed volume and being connected to air sacs. Playing the same role as alveoli, they have air capillaries that form a three-dimensional mesh with blood capillaries, significantly enhancing gas exchange capacity (DUNCKER, 1974; FEDDE, 1998; POUGH et al., 2003; MAINA, 2006; SAMUELSON,
2007; FRANZO et al., 2009; MATSUMOTO et al., 2009).

Knowledge on the respiratory tract of birds, as well as its operation, is crucial not only for providing these animals with treatment, but also to avoid unwanted accidents during handling (ROSSKOPF; WOERPEL, 1996). Given that histological studies in wild birds are scarce, this study aimed to microscopically describe the lung of two wild bird species, detailing its structures, in order to provide broader knowledge of some features of these species.

\section{Material and Methods}

For the histological lung description, we used a female Ardea alba individual and a male Caracara plancus individual, taken to the Center for Rehabilitation of Wild Animals (CRAS) of Universidade Estácio de Sá (UNESA), in Vargem Pequena, Rio de Janeiro, Brazil; they were properly identified by a trained professional and registered at the time of entry into the institution. The birds died naturally, and then their bodies were donated for analysis in this study, which was approved by the Ethics Committee of the Educational Foundation "Dom André Arcoverde", under the Protocol CEUA 09/2012.

Just after the death of the animals, dissection of the viscera was carried out; they were fixed by immersion in 10\% Millong formalin (CARSON et al., 1973). After 48 hours, needed for fixing, the material was dehydrated in increasing ethanol concentrations, from $70 \%$ to $100 \%$, then diaphanized in xylene and included in a paraffinlike substance (Histosec ${ }^{\circledR}$-Merck Embedding Media - Germany). We made $5 \mu \mathrm{m}$ cuts by using microtome (CUT 4055 Microtome) and subsequently stained the 
material by using the hematoxylin and eosin technique; in addition to orcein (TOLOSA et al., 2003).

The microscopic images were recorded by means of a Zeiss Primo Star Student Binocular Microscope coupled to a digital camera.

\section{Results and Discussion}

The lung in both birds under study, as well as poultry, occupies most of the thoraco-abdominal cavity, it is located in dorsal cranial region, against the thoracic vertebrae and ribs, being marked by them (DUNCKER, 1974; POUGH et al., 2003; SAMUELSON, 2007). Having a fixed volume, not lobed and connected to the air sacs, which serve ventilatory apparatus to the lungs, characteristic bronchial structures were viewed, just as observed in Gallus gallus, Cairina moschata (NGANPIEP; MAINA, 2002; BACHA; BACHA, 2003; MAINA, 2006; MAKANYA; DJONOV, 2009), and Struthio camelus (MAINA; NATHANIEL, 2001): mesobronchus or primary intrapulmonary bronchus, secondary bronchi and tertiary bronchi, named parabronchi (figures 1A and 1B).
In both species, the histology of mesobronchus is very similar, having a pseudo-stratified cylindrical epithelium with cilia, goblet cells, and intraepithelial mucous glands. It also exhibits a lamina of its own, consisting of loose connective tissue and continuous muscle with a preferably circular direction (Figure 2). We did not observe cartilage plates, as described by Samuelson (2007), who reports the presence of cartilaginous rings in extrapulmonary bronchi of $G$. gallus, which are replaced by cartilage plates that disappear in the initial portion of mesobronchus.

The secondary bronchi of both birds showed a cubic epithelium with cilia and absence of goblet cells and mucous glands. Corroborating Fedde (1998) and Samuelson (2007), who describe that, except for the absence of goblet cells, the epithelium of secondary bronchi is similar to that of mesobronchus. There is an apparent discontinuous muscle layer, with multidirectional orientation and transition towards parabronchus, corroborating Bacha and Bacha (2003); we viewed an epithelial change, with the emergence of discontinuity areas, giving rise to structures named atria (Figure 1B).

FIGURE 1: Photomicrograph of the lung of great egret showing the image of mesobronchus or primary intrapulmonary bronchus (arrow) (A). In B, we observe in the lung of southern caracara, branching of the secondary bronchus into tertiary bronchi, named parabronchi (arrows). Also observe the epithelial change and the emergence of atria (a). HE stain.
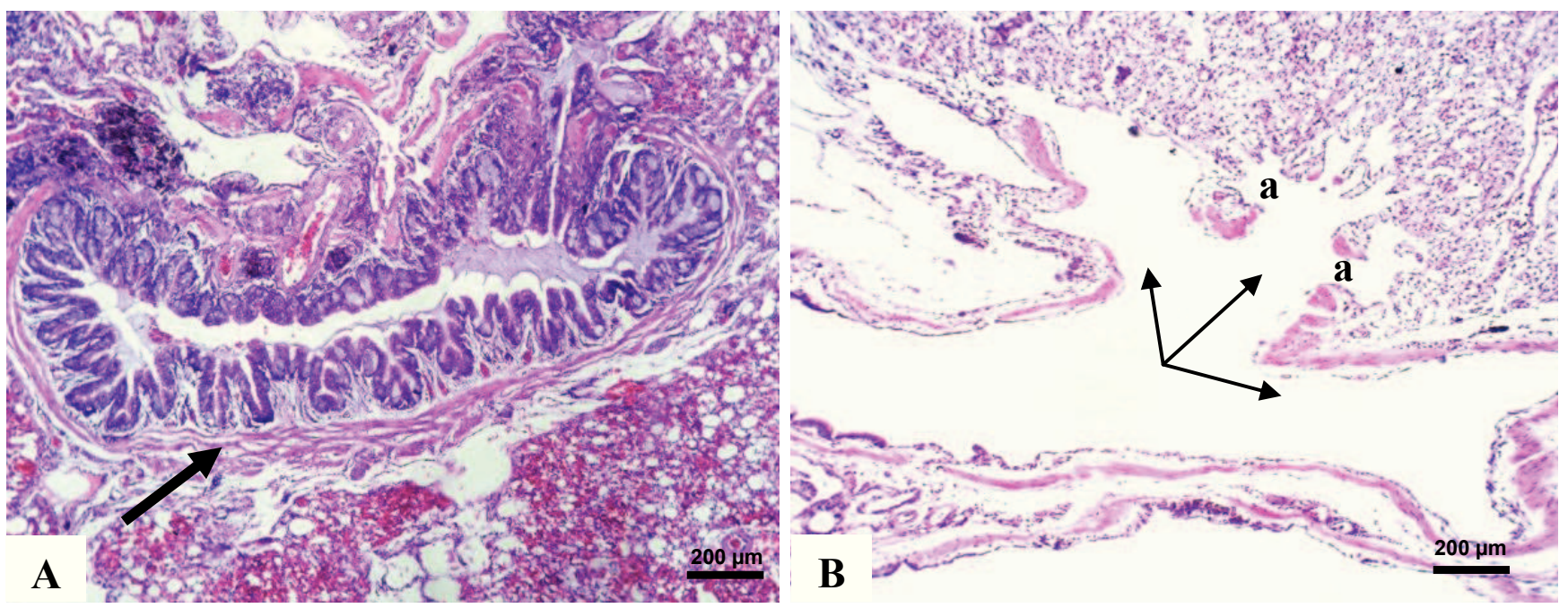
FIGURE 2: Photomicrograph of the lung of great egret showing the image of mesobronchial mucosa. We notice the ciliated epithelium (thin arrow) and the presence of intraepithelial glands (thick arrows). HE stain.

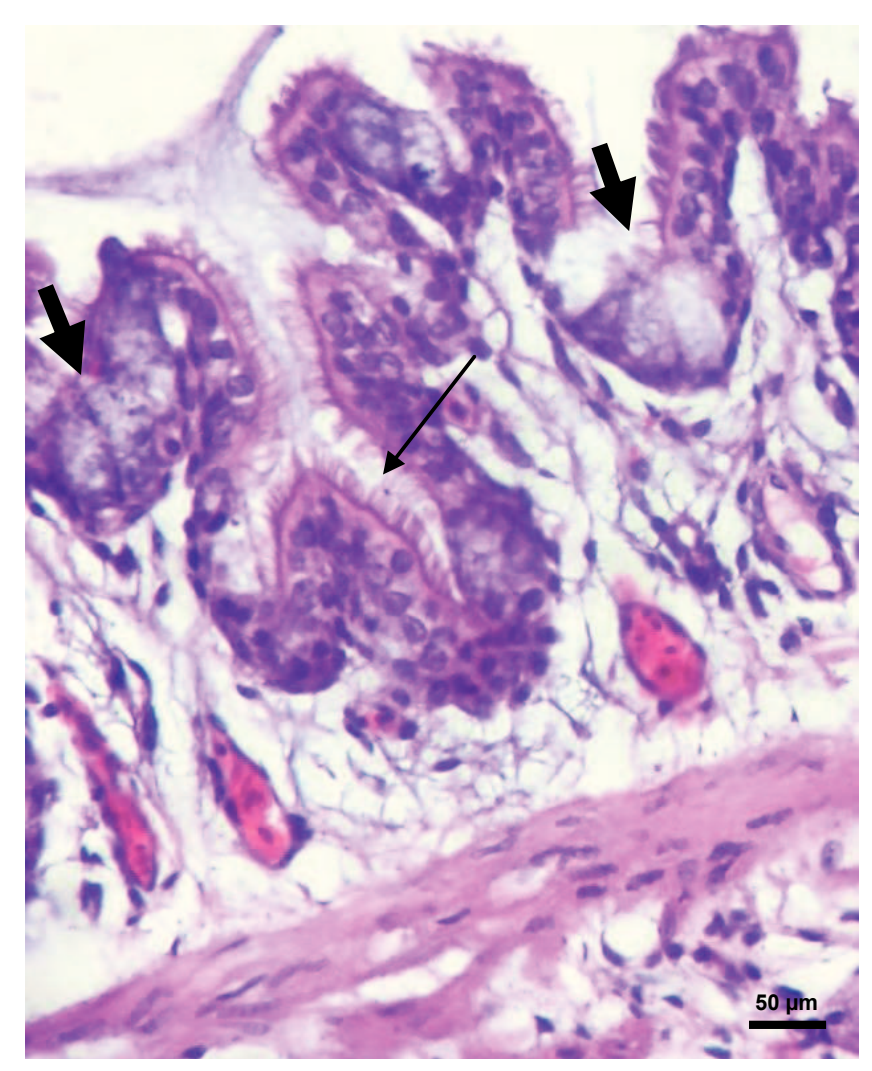

The parabronchus is considered as the functional unit of the lungs of birds, and it is responsible for gas exchange (DUNCKER, 1974). Immediately after its origin, from the inner surface of secondary bronchi, we found out in the described species, corroborating Heard (1997), that parabronchi are long narrow tubes with a high degree of anastomosis.

The inner surface of the tubular parabronchi is pierced by numerous openings named atria or air vesicles, formed by a cubic or squamous epithelium without cilia, separated by septa. Named interatrial, septa have a loose connective tissue showing an extended apex due to the presence of smooth muscle cells functionally connected to elastic fibers (Figure 3A). These histological findings confirm what Duncker (1974), Scheuermann et al. (1997), and Klika et al. (1996) described; these authors also indicate that there may be a variation in parabronchial light due to contraction or relaxation of smooth muscle fibers along with the elastic system fibers, which extend into the atrial septum.

Emerging from the atrium, we notice the presence of funnel-shaped ducts named infundibulum, consisting of squamous epithelial cells, which drives air through air

FIGURE 3: Photomicrograph of the lung of great egret showing the elastic system fibers (arrows) using specific staining - Orcein. In B, parabronchus of the lung of southern caracara, showing atrial muscle (am), atrium (a), interatrial septum (is), infundibulum (i), and air capillary (arrows). HE stain.

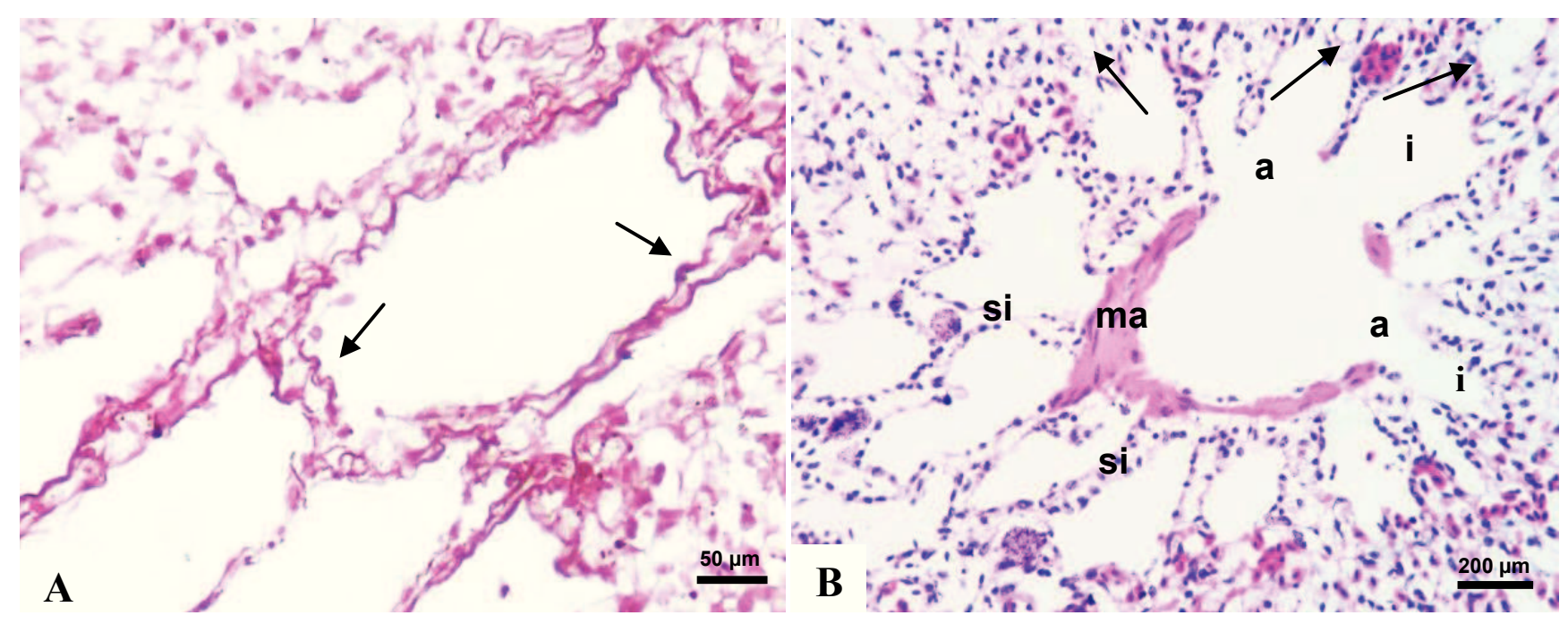


capillaries. Over their length, air capillaries anastomose and constitute a three-dimensional mesh around the capillaries, filling the interstitium, something which enhances the efficiency of gas exchange, as described by Klika et al. (1996), Orosz (1997), Scheuermann et al. (1997), Fedde (1998), Maina (2006), and Maina and Woodward (2009) (Figure 3B).

Both great egret and southern caracara showed both parabronchi patterns: the neopulmonary, which constitutes a random mesh of anastomosed parabronchi, being absent in Spheniscus magellanicus and underdeveloped in Struthio camelus; and the paleopulmonary, which is observed in all bird species, represented by parallel stacks of anastomosed parabronchi, a result that corroborates what is described in the literature regarding the functional pattern of parabronchi in some bird species (DUNCKER, 1974; HEARD, 1997; OROSZ, 1997; FEDDE, 1998; MAINA, 2006; MAINA; NATHANIEL, 2001).

We found out that, microscopically, the lung of the species under study showed a very similar pattern to that described in the literature for poultry, confirming the complex architecture to enhance the efficiency of haematosis.

\section{References}

BACHA, W. J.; BACHA, L. M. Color atlas of Veterinary Histology. 2 ed. São Paulo: Roca, 2003. 457 p.

CARSON, F. L. ; MARTIN, J. H. ; LYNN, J. A. Formalin fixation for electron microscopy: a re-evaluation. American Journal of Clinical Pathology, New York, v. 59, n. 3, p. 365-373, 1973.

DUKES, G. E. Digestão nas aves. In: SWENSON, M. J.; REECE, W. O. (Ed.). Fisiologia dos animais domésticos. Rio de Janeiro: Guanabara Koogan, 1996. p. 390-397.

DUNCKER, H. R. Structure of the avian respiratory tract. Respiration Physiology, Amsterdam, v. 22, p. 1-19, 1974.

FEDDE, M. R. Relationship of structure and function of the avian respiratory system to disease susceptibility. Poultry Science, Savoy, v. 77, p. 1130-1138, 1998.

FRANZO, V. S.; ARTONI, S. M. B.; VULCANI, V. A. S.; BARREIRO, F. R.; WERTHER, K.; SAGULA, A. Considerações biométricas do sistema respiratório de carcará (Polyborus plancus). Ciência Rural, Santa Maria, v. 39, n. 1, p. 250-253, 2009.

HEARD, D. J. Avian respiratory anatomy and physiology. Seminars in Avian and Exotic Pet Medicine, Baton Rouge, v. 6, n. 4, p. 172-179, 1997.
KLIKA, E.; SCHEUERMANN, D. W.; GROODT-LASSEEL, M. H. A.; BAZANTOVA, I.; SWITKA, A. Pulmonary macrophages in birds (Barn Owl, Tyto tyto alba), domestic Fowl (Gallus gallus f. domestica), Quail (Coturnix coturnix), and Pigeons (Columbia livia). The Anatomical Record, Hoboken, v. 246, p. 87-97, 1996.

MAINA, J. N. Development, structure, and function of a novel respiratory organ, the lung-air sac system of birds: to go where no other vertebrate has gone. Biological Reviews, Cambridge, v. 81, p. 545-579, 2006.

MAINA, J. N.; NATHANIEL, C. A qualitative and quantitative study of the lung of an ostrich, Struthio camelus. The Journal of Experimental Biology, Cambridge, v. 204, p. 2313-2330, 2001.

MAINA, J. N.; WOODWARD, J. D. Tree-dimensional serial section computer reconstruction of the arrangement of the structural components of the parabronchus of the Ostrich, Struthio camelus lung. The Anatomical Record, Hoboken, v. 292, p. 1685-1698, 2009.

MAKANYA, A. N.; DJONOV, V. Parabronchial angioarchitecture in developing and adult chickens. Journal of Applied Physiology, Bethesda, v. 106, n. 6, p. 1959-1969, 2009.

MATSUMOTO, F. S. ; CARVALHO, A. F.; FRANCIOLLI, A. L. R.; FAVARON, P. O.; MIGLINO, M. A.; AMBROSIO, C. E. Topografia e morfologia das vísceras do periquito-australiano (Melopsittacus undulatus, Shaw, 1805). Ciência Animal Brasileira, Goiânia, v. 10, n. 4, p. 1263-1270, 2009.

NGANPIEP, L. N.; MAINA, J. N. Composite cellular defence stratagem in the avian respiratory system: functional morphology of the free (surface) macrophages and specialized pulmonary epithelia. Journal of Anatomy, London, v. 200, n. 5, p. 499-516, 2002.

OROSZ, S. Respiratory system: anatomy of the respiratory system. In: ALTMAN, R. B.; CLUBB, S. L.; DORRESTEIN, G. M.; QUESENBERRY, K. (Ed.). Avian medicine and surgey. Cap. 25. Philadelphia: W. B. Sauders, 1997. p. 387-390.

POUGH, F. H.; JANIS, C. M.; HEISER, J. B. A evolução das aves e a origem do vôo. In: POUGH, F. H.; JANIS, C. M.; HEISER, J. B. (Ed.). A vida dos vertebrados. 3. ed. São Paulo: Atheneu Editora, 2003. p. 409-445.

ROSSKOPF, W. J.; WOERPEL, R. W. Diseases of cage and aviary birds. 3 ed. Philadelphia: Williams \& Wilkins, 1996. 1088 p.

SAMUELSON, D. A. Tratado de Histologia Veterinária. Rio de Janeiro: Elsevier, 2007. 527 p.

SCHEUERMANN, D. W.; KLIKA, E.; DE GROODT-LASSEEL, M. H. A.; BAZANTOVA, I.; SWITKA, A. An electron microscopic study of the parabronchial epithelium in the mature lung of four bird species. The Anatomical Record, Hoboken, v. 249, p. $213-$ 225,1997

SICK, H. Ornitologia brasileira, uma introdução. Rio de Janeiro: Editora Nova Fronteira, 1997. 912 p.

TOLOSA, E. M. C.; RODRIGUES, C. J.; BEHMER, O. A.; NETO, A. G. F. Manual de técnicas para histologia normal e patológica. 2. ed. São Paulo: Manole, 2003. 341 p. 